\title{
Review Article: Souls, Hearts and Heritage: Passing from the Danube to the Hudson. Szegedy-Maszák, Marianne. 2013. I Kiss Your Hands Many Times - Hearts, Souls and Wars in Hungary. New York: Spiegel \& Grau, Random House. 345 pp; and Griesz, Katherine. 2012. From the Danube to the Hudson. Seattle, WA: CreateSpace Independent Publishing. 482 pp.
}

\section{Evi Blaikie}

\begin{abstract}
How did the rich and the super-rich Hungarian Jews in Budapest fare during the 1930s, World War II and the Holocaust, and beyond? Two new books deal with their stories: Marianne Szegedy-Maszák's I Kiss Your Hands Many Times and Katherine Griesz's From the Danube to the Hudson. Szegedy-Maszák was able to use her journalist's profession and skills to explore and vividly present her family's story in a work that can likewise satisfy the historians, the romantics and all those who like a "good read." Griesz's epic family memoir encompasses the same time period and topic as Szegedy-Maszák's book in its portrayal of a multi-generational Hungarian Jewish family's fate in the crisis full mid-twentieth century, as seen and interpreted by its female descendant decades later.
\end{abstract}

Keywords: Memoir, war and life writing, Hungarian Jews, World War II, Holocaust, 1956 Hungarian Revolution

Biography: Evi Blaikie (née Weisz), author of Magda's Daughter - a Hidden Child's Journey Home (City University of New York Feminist Press, 2003), and Remember Us - a Collection of Memories from Hungarian Hidden Children of the Holocaust (ed. Judy Abrams; Bloomington, IN: AuthorsPress, 2009), is a founding member of the Hungarian Hidden Children of New York, Inc.

Close to seventy years after the Holocaust there still continue to appear personal memoirs by survivors as well as now by their second-generation children, which can add information that history does not deal with. Most such works have been written by those of the assimilated middle classes, with memoirs by both the poor and the very religious, who perished in far higher numbers. (see Vasvári 2009, as well as earlier reviews of memoirs in this journal by Blaikie 2009). The memoirs under review here are not about the fate of the persecuted masses but about how the rich and the super-rich Hungarian Jews in Budapest fared during the 1930s, World War II and the Holocaust, and beyond. Two new books deal with their stories: Marianne Szegedy-Maszák's I Kiss Your Hands Many Times and Katherine Griesz's From the Danube to the Hudson.

(cc) $\mathrm{Br}$

ULLS D-Serle 
Blaikie, Evi. "Review Article: Souls, Hearts and Heritage: Passing from the Danube to the Hudson. SzegedyMaszák, Marianne. 2013. I Kiss Your Hands Many Times and Griesz, Katherine. 2012. From the Danube to the Hudson." Hungarian Cultural Studies. e-Journal of the American Hungarian Educators Association, Volume 7 (2014): http://ahea.pitt.edu DOI: 10.5195/ahea.2014.143

Szegedy-Maszák, great-granddaughter of Manfred Weiss, a Jewish early twentieth century and inter-war industrialist and multi-millionaire, and daughter of Aladár SzegedyMaszák, Hungary's first post-war ambassador to the United States, intertwines her family's impressive (hi)story with an intimate account of her parents' poignant and enduring relationship. Born in the U.S., Szegedy-Maszák does not speak Hungarian. Only after the deaths of her parents did she venture into and then recreated their personal pasts by reading through their love letters and diaries, which she first had to have translated. Thus she became acquainted with them not as the parents that she knew but as their younger selves. Szegedy-Maszák's revelations caused her to write about her parents lovingly, describing their courtship as wistful, gentle yet tenacious, as well as fraught with crises and long separations.

Obviously of great interest to Hungarians, the book was immediately translated, under the title Csókolom a Kezét (Budapest: Libri könyvkiadó, 2014). The translation received a positive review in Nök Lapja [The Women's Magazine] of May 22, 2014. It is of greater interest, however, that Imre Kerényi's editorial in NOL E-Magazine (of June 8, 2014) claimed that Szegedy-Maszák's book and family history proved that if it were not for the Germans invasion of Hungary, there would have been no deportations of Jews, as Hungary had been a safe haven to them, similar to Sweden or Switzerland. Szegedy-Maszák forcefully countered (in June 11, 2014) that neither of these two countries enacted laws depriving Jews of their rights and property, nor sent Jewish men as unarmed degraded soldiers to be slaughtered in the Russian front (http://nol.hu/velemeny/a-konyvem-helye-1467257, retrieved June 27, 2014).

Manfred Weiss and his wife, née Alice de Wahl, had six children and three of their four daughters married men who were also captains of industry and socially or politically prominent. Two sons-in-law, Moric Kornfeld, the writer's maternal grandfather (Baron Móric Kornfeld 2007; Tamás Kornfeld 2014), and Ferenc Chorin, her great uncle, proved to be exceptional businessmen who consolidated huge wealth and power in the family's hands. The Weiss steel and iron factories, located in Csepel Island in the middle of the Danube, at one time employed 40,000 workers. Kornfeld and Chorin jointly directed and navigated the family through the stormy waters of World War II, the Holocaust, and the period after the war, in which they already lived in the West. On the writer's father side, the Szegedy-Maszáks were a distinguished old Christian family. The writer's paternal grandfather had been close to Emperor Francis Joseph, and her grandmother acted as a leader in the Catholic Women's League, but the family lived in relatively modest circumstances, with their son Aladár supporting his parents and older sister Lilly.

The handsome and talented Aladár, the up-and-coming diplomat and confirmed bachelor, was a frequent visitor at the Kornfelds, where the intelligentsia of Budapest often assembled. In 1940, he met Hannah, the Kornfeld reserved and refined oldest daughter, and started courting her, though at first very discretely. Although Hannah had converted in 1920, in the anti-Jewish and racist atmosphere of the late 1930s and early 1940s, Aladár feared that her Jewish origin might harm his diplomatic career. Szegedy-Maszák introduces us to the pre-war lifestyle of the Weiss/Kornfeld/Chorin families, which was reminiscent of the British upper classes of those times, with its civilized manners, understated elegance, refinement and cultural pursuits; in fact, the writer mentions how at-home their British friends felt when visiting them. 
Blaikie, Evi. "Review Article: Souls, Hearts and Heritage: Passing from the Danube to the Hudson. SzegedyMaszák, Marianne. 2013. I Kiss Your Hands Many Times and Griesz, Katherine. 2012. From the Danube to the Hudson." Hungarian Cultural Studies. e-Journal of the American Hungarian Educators Association, Volume 7 (2014): http://ahea.pitt.edu DOI: 10.5195/ahea.2014.143

Despite its enormous wealth, the large, close-knit family was thrifty, hard working, and famously philanthropic, with the women seriously engaged in good works, although at the same time they also enjoyed great luxury. Besides spacious mansions in Budapest, where they all resided, the family regularly gathered at Ireg in their 6,000 acre summer residence and in a hunting lodge where they spent the winter holidays. It would have been interesting to see more pictures of the family in those years, instead of only a handful of minuscule, almost indistinguishable photographs occasionally appearing without captions, as those are buried at the end of the book.

The idyllic life enjoyed by the Kornfeld/Chorin family in the 1920s and the early 1930s changed as the winds of war approached. Several family members had converted to Christianity in those decades, some out of conviction and others out of convenience, while some others steadfastly refused to do so. All however acknowledged their Jewish roots, which may be the reason why, when Hannah and her sister, Puppa, "went to some parties at the homes of Gentile girls, they always felt like outsiders" (52). In the next generation, however, the writer already grew up as a church-going Catholic with devout parents. Since both sides of her family played important roles in Hungary's political, economic and diplomatic life, Szegedy-Maszák gives a detailed account of the family's involvement in the history of the country from the 1930s to the communist takeover after World War II. Aladár was an envoy to Berlin in the 1930s, where he witnessed Hitler's ascent, and referred to the Nazi ideology as a "mass-psychosis." His staunch anti-Nazi convictions endangered his diplomatic career in the increasingly anti-Semitic, right leaning Hungarian politics and atmosphere, and eventually landed him in the notorious Fö utca jail, from where he was later deported to Dachau.

Meanwhile, the Kornfeld/Chorin factories reluctantly worked at full tilt, manufacturing Messerschmitt engines and other ammunition for the Nazi war effort. Aladár Szegedy-Maszák's frustration and worries for his homeland were agonizing, yet neither he nor, ironically, the unwilling Jewish "arms manufacturers" considered leaving the country. Aladár had an overwhelming sense of duty to his family and loyalty to his country, which was being taken over by thugs and he was helpless in stopping this advance. The Kornfeld/Chorin position is more difficult to understand. They relied on their position and fortune to save them from the fate of their fellow Jews, which, ultimately, did happen. After the German invasion, the two heads of the family were arrested and suffered humiliation and torture. Other members of the family scrambled, hiding and running from place to place, until they were all gathered together, and Ferenc Chorin negotiated a deal that made headlines around the world: forty members of the Kornfeld/Chorin tribe were flown out of Hungary to the safety of neutral Portugal and Switzerland. The secret and complicated deal involved ceding the family fortune and factories to Heinrich Himmler, who had Hitler's personal permission for making such an arrangement and thus enraged his rival, Von Ribbentrop, as well as the Hungarian government. Though four family members were kept as hostages until the deal went through, eventually the whole family survived intact and was allowed to leave. The more astounding fact was that the Nazis kept their part of the bargain (on world Jewry rescue attempts of the time see: Szita 2005; "Becher Seizes Weiss Family Wealth" at: http://www.clintonlibrary.gov/assets/storage/)

The story of the family's life in exile in Portugal and Switzerland, waiting interminably for the end of the war and the issuance of their U.S. visas, might have been better were it less detailed with the circumstances and doings of various and sundry family members, repeatedly 
Blaikie, Evi. "Review Article: Souls, Hearts and Heritage: Passing from the Danube to the Hudson. SzegedyMaszák, Marianne. 2013. I Kiss Your Hands Many Times and Griesz, Katherine. 2012. From the Danube to the Hudson." Hungarian Cultural Studies. e-Journal of the American Hungarian Educators Association, Volume 7 (2014): http://ahea.pitt.edu DOI: 10.5195/ahea.2014.143

sending the reader scurrying to the family tree at the beginning of the book, only to find that it fails to present the birth and death dates of those persons. Instead of this leafing back and forth, at least this reader would have preferred to tarry awhile with, e.g., Puppa, the writer's aunt and a provocative and intriguing character in her own right. Amazingly, following the ordeal of exile, internment and lack of communication for two years, Hannah and Aladár were reunited after the war and married in Budapest before he was named Ambassador to the U.S., where he fought fruitlessly to stop the communist takeover of his country. His short-lived ambassadorship was fraught with frustrations and he eventually resigned when the communists took power. Weakened by his wartime experiences, disappointed in being unable to save his country or even return to it, this incorruptible, highly principled man was unable to bend and fell into a depression that lasted to the end of his life.

The writer begins and ends the book with an account of her family's life in Washington, DC. So far, three generations have been living there together in harmony, totally reconciled to their diminished wealth, but with memories of events that the younger generation would never be able to match. As for recapitulating and telling about it all some seventy years after the event, Marianne Szegedy-Maszák was able to use her journalist's profession and skills to explore and vividly present her family's story in a work that can likewise satisfy the historians, the romantics and all those who like a "good read."

Katherine Griesz's epic family memoir, From the Danube to the Hudson, encompasses the same time period and topic as Szegedy-Maszák's book, but her work lacks the engaging quality and the focus of I Kiss Your Hands. Though obviously this family, too, had means, their lifestyle and wealth did not compare to those of the Weiss/Kornfeld/Chorin family. Moreover, this family is indicative of many of the upwardly mobile interwar merchant class Jews of Budapest, who became nouveau riches, emulating the lifestyle of the truly wealthy, and thereby acquiring a pretentiousness that actually laid bare their much humbler origin.

Griesz's grandfather, Ignatius (whose last name is never mentioned in the book) was a very successful purveyor of exotic and rare foodstuffs and owned a large company by the name of Colonus in Budapest. Ignatius' daughter, Magda, is in fact the central -- in the sense of active -- character of the memoir, rather than her daughter Kati, the author. Magda grows up spoiled, idle and unhappy because her father refuses to allow her to work in his establishment, telling her to "go shopping, read, play the piano, embroider...." (9). Education and good works are evidently no alternatives for Magda, so she marries to escape her father's authority and soon becomes the mother of Kati. The marriage, however, is doomed to fail on account of Magda's incapacity to share her husband's more intellectual interests. Incomprehensibly, only after her divorce, aged thirty-three, does Magda first become aware of her ethnicity, when her father agrees to pay for her plastic surgery to make her look less, as he calls it, "racially identifiable," which her mother "translates" as "less Jewish" (48). Still, beyond this incident, Magda is so unaware of the 1930s socio-political state of things in Hungary that in 1938, upon the enactment of the first Jewish Law in the country, she exclaims: "It is the first time I've heard of an antiJewish law here in Hungary" (102). In reality, already in 1920, Hungary was the first European country to enact the Numerus Clausus Act that limited the admittance of Jews to universities in proportion to their percentage in the general population. 
Blaikie, Evi. "Review Article: Souls, Hearts and Heritage: Passing from the Danube to the Hudson. SzegedyMaszák, Marianne. 2013. I Kiss Your Hands Many Times and Griesz, Katherine. 2012. From the Danube to the Hudson." Hungarian Cultural Studies. e-Journal of the American Hungarian Educators Association, Volume 7 (2014): http://ahea.pitt.edu DOI: 10.5195/ahea.2014.143

Despite the prevailing anti-Semitic atmosphere, Magda sends her daughter to attend Jewish religious classes, where Kati embraces the religion and adopts her teacher, Rabbi Herzog, as a father figure, as she and Magda's new husband, Gábor, have taken an instant dislike to each other. Soon afterward, however, the family converts to Christianity and Kati is sent to a Calvinist Young Ladies Academy boarding school, with the help of Eugene Paal, Ignatius' sycophantic gentile employee, because her family believes that the this school "caters to the children of aristocrats, landowners and the gentry, and they emphasize their strong Hungarian tradition" (121). Yet, being of Jewish origin, Kati becomes the target of vicious anti-Semitic attacks in the Academy. Eventually she leaves, but even then she seems more bothered by the low class of her past schoolmates than by their anti-Semitism: "only some of them ....come from the finest aristocratic family.... Others are the children of country sheriffs, bailiffs, and district administrators" (138). When Kati's first cousin Claire and her husband Freddie wisely decide to emigrate to Australia, there is much consternation in the family, because they do not even know where Australia is. Grandfather Ignatius, the worldly businessman, venture a guess: "I think it must be far away. I am only familiar with the countries I do business with" (112).

World War II breaks out, Ignatius dies, and the men in the family are sent into internment and to labor battalions in the Hungarian army. When the German army occupies the country and marches into Budapest on March 19th 1944, the situation for Jews becomes desperate. Magda and her family are forced to wear the yellow star, but she still insists on not knowing that other Jews even live in the same building as her (166). Soon afterward the family is thrown out of their apartment by the anti-Semitic caretakers and crammed into a "Jewish House" (marked by a yellow star) in the city. Instead of hiding the family's valuables, as most Jews did at the time, Magda and her mother simply give up everything when ordered to do so.

In these most dangerous times, the spoiled Magda comes into her own, "[takes] charge of the kitchen and [begins] to cook" (174). She now becomes the true heroine of this family saga, and even manages to get food from her father's store, which is by then run by the perfidious and hostile Eugene Paal. Later, through Ignatius' erstwhile business contacts with Portugal, the family finds shelter in a Portuguese Ambassadorship Safe House in Budapest, but with the Soviet army already surrounding the Capital, the Nyilas [Arrow Cross] squads march all the House occupants into the ghetto, where Magda, Gábor (who has been away and recently reappeared) and Kati barely survive. Only after Liberation does Kati find out that her first love, Jani, was shot into the Danube, along with her father and the beloved Rabbi Herzog.

Once the war is over, there is no further mention of Jews, Jewish life, or any Jewish practice in this epic memoir, except in the very last pages, where in the 1990s and after many years abroad, Kati and her husband return to Hungary and he visits his parents' graves in the Budapest Jewish cemetery. In the immediate postwar period, the family manages to restore the foodstuffs business, and Magda insists on being part of it, "but," says the writer, at thar time "it was still something of a novelty for a woman of her class and circumstances to work" (214). Life for Magda and Kati resumes with all its pre-war luxuries and pleasures. Soon, however, as the communists gain more power, Kati is sent to Switzerland to study hotel management, while Magda and Gábor try to escape Hungary. The escape fails and they are subjected to interrogation at the dreaded and notorious AVO - Államvédelmi osztály [State Security Agency] headquarters at Andrássi Ut 60, after which they are imprisoned at Kistarcsa, the erstwhile Nazi internment camp, by now turned into a communist jail. 
Blaikie, Evi. "Review Article: Souls, Hearts and Heritage: Passing from the Danube to the Hudson. SzegedyMaszák, Marianne. 2013. I Kiss Your Hands Many Times and Griesz, Katherine. 2012. From the Danube to the Hudson." Hungarian Cultural Studies. e-Journal of the American Hungarian Educators Association, Volume 7 (2014): http://ahea.pitt.edu DOI: 10.5195/ahea.2014.143

Early on, while being interrogated, Magda destroyed the numbers of the family's Swiss bank accounts, which are now forever lost to the family as Magda failed to memorize the account numbers. It is never explained why her brother, Emery, does not even know about the accounts, let alone their numbers. To counterbalance this failure she does manage to instruct Kati, from jail, about emigration to Australia, by now a familiar country of rescue to this family... But Kati arrives there only after a few years in Switzerland, where she runs out of funds, finds a job and is victimized by her Swiss employers. Kati eventually emigrates to Australia, where she feels unwelcomed by her cousin Claire, since she brings no money with her. She takes menial jobs and lives on her own, constantly bemoaning her fate and comparing it to her prewar life in Hungary. She is encouraged to take courses, but she demurs and enters into a disastrous marriage to an abusive crook, from whom she manages to part, but she cannot obtain a divorce nor leave the country for the next five years.

After their release from jail, Magda and Gábor struggle through the years behind the Iron Curtain, until the 1956 Revolution, when they are able to escape to Vienna and from there to Australia. They arrive with a hundred dollars collected on their behalf by the passengers on the ship that brought them, which makes Kati indignant and devastated at the loss of Ignatius's money. Kati now takes a secretarial course, her first attempt to improve herself and assume responsibility for her life, while Magda immediately gets to work, saves, manages to buy a house and even supports Kati. Kati then gets her divorce and decides to move to England, apparently giving little thought to leaving behind her mother, whom she "adores" and calls "my best friend"(373), but towards whom she feels no responsibility. Kati seems to excuse herself out of any judgment by praising her mother that "one of her most admirable traits was that she never complained, nor did she give in to self pity" (461), a trait that unfortunately did not pass to Magda's daughter.

In later decades, the 1960 and 1970s, Magda follows Kati to London with her ailing husband and gets work as a cook and housekeeper to the President of the Royal Institution. Again, Magda manages to save, buy real estate, and make a home for Kati, only to have Kati leave for Vienna, where she accepts a marriage proposal from a Hungarian-American, and the couple lands in New York, Kati's dream place since her childhood. She works at various jobs and helps her middle aged husband acquire a college degree in order to advance his career. Magda occasionally visits them but eventually returns to Australia, where she has made her home, and where she dies before Kati can see her one last time. Thus ends this mainly mother and daughter's saga of survival and many emigrations, marital and familial ups and downs, and financial and other losses and new starts.

As for structure and tellability, throughout its almost 500 pages, the book lacks focus and is way too long for its core narrative, largely due to ponderous, pedantic and contrived dialogues, as to many irrelevant details, which a competent editing should have rectified. Yet, the merit of this book, like that of Szegedy-Maszák's I Kiss Your Hands, is in its epic portrayal of a multigenerational Hungarian Jewish family's fate in the crisis-full mid-twentieth century, as seen and interpreted by its female descendant decades later. 


\section{Works Cited}

"Becher Seizes Weiss Family Wealth," at: http://www.clintonlibrary.gov/assets/storage/Research\%20\%20Digital\%20Library/holocaust/theft/Box\%20184/6997222-alberts-research-notes$2 . p d f$

Blaikie, Evi. Remember Us - a Collection of Memories from Hungarian Hidden Children of the Holocaust (ed. Judy Abrams). Bloomington, IN: AuthorsPress, 2009.

Kornfeld, Baron Móric. 2007. Reflections on Twentieth Century Hungary - A Hungarian Magnate's View (Trans. Tamás J. DeKornfeld and Helen D. DeKornfeld, with a personal recollection by Tamás J. DeKornfeld; ed. with a Preface and Introduction Ágnes Széchenyi). Bolder, CO: Social Science Monographs; New York: Distribution of Columbia UP; Wayne, NJ: Center of Hungarian Studies and Publications (CHSP), no. 14 (series eds. Peter Pastor and Ivan Sanders); Budapest: Institution of Habsburg History, 2007.

Kornfeld, Tamás. 2014. Nem mindennapi élet [Not an Everyday Life]. Budapest: Corvina Kiadó. Szita, Szabolcs. 2005. Trading Lives - Operations of the Jewish Relief and Rescue Committee, 1944-1945. Budapest: Central European University Press.

Stewart, Victoria. 2005. "Holocaust Diaries: Writing from the Abyss" Forum of Modern Language Studies 41.4: 418-426.

Vasvári, Louise O. 2009. "Introduction to and Bibliography of Central European Women's Holocaust Life Writing in English." Comparative Central European Holocaust Studies. Eds. Louise O Vasvári \& Steven Tötösy.Purdue UP \& CLCWeb 11.1(2009), at: http://docs.lib.purdue.edu/clcweb/vol11/issue1/10 